\title{
Section 8. Philology
}

https://doi.org/10.29013/ESR-19-9.10-54-57

Ayakulov Nurbek Abdug'appor o'g'li,

$P h D$ researcher, Uzbekistan State

World Languages University (UzSWLU)

E-mail: nurbek.ayaqulov.1992@gmail.com

\section{ANGLICISMS IN SPORT TERMINOLOGY OF THE UZBEK LANGUAGE AND ITS DIFFICULTIES IN TRANSLATION}

Abstract. This article deals with borrowing vocabulary in the field of sports from English to Uzbek. It is established that in the Uzbek sports terminology there is a large number of anglicisms, which is explained by the development of appropriate technology for various sports in the English-speaking world. In the course of the study, a lexico-semantic analysis of Uzbek sports terms of English origin is carried out, and also the peculiarities of their word formation are revealed.

Keywords: sports terms; borrowing; anglicisms; affix word formation.

\section{Intruduction}

In the process of globalization and the dominance of the English language in the status of the language of international communication, it seems logical to penetrate Anglicisms into other languages, for example, into Uzbek. Borrowing from the English language covers various areas of human activity: economics, information technology, gastronomy. Sport is not an exception, since "the modern stage in the development of sport, especially sport of higher achievements, is characterized by its internationalization".

In this paper, we will adhere to a broad understanding of sport, i.e. as some physical or mental activity based on certain rules, requiring the presence of specially equipped places or special equipment and aimed at developing and strengthening the body and getting pleasure or vivid emotions. Such an approach makes it possible not to be limited only to institutionalized kinds of big-time sports and toplevel sports.

\section{Method of research}

In this article we use comparative typological method which show us features of Uzbek and English sport terminology in translation.

\section{Main part}

In addition, sports are divided into groups based on distinctive features. E. I. Gureeva gives a detailed classification and allocates dynamic (winter, summer and air) and static (self-intellectual and technical-model) sports. The researcher also cites the conceptual microsystem of a separate sport, which includes the concepts of "place", "athlete", "technical and tactical methods", "projectile", "ammunition", "quality", "quantity" [1].

All of the above constitutes the conceptual content of the concept "sport". Sport as such and its conceptual system consist of many components and conceptual subsystems. Moreover, sport borders, and sometimes merges with other conceptual macrofields. In the language of sports, you can find 
terms that simultaneously refer to the concepts of both physical and medical nature (for example, the designations of injuries, chemicals, features of physical development); terms included in the term "sport" and "law" (names of violations of the regulations, rules, anti-doping legislation, etc.), etc. A natural question arises: what language signs are considered sports terms? More precisely, what concepts sports terminology refers to?

N.A. Shafranova understands sports vocabulary as a layer of the vocabulary of the language, reflecting professional and recreational human activity that requires physical and volitional effort [2]. A.A. Elistratov writes that "sports terms include concepts on the most common sports, as well as on the theory and methodology of physical culture, related scientific and academic disciplines (biomechanics, psychology, pedagogy, hygiene, sports physiology, sports medicine and biochemistry)" [3]. In sports dictionaries, vocabulary, denoting common concepts for many sports, is marked as sports-wide or is allocated to a separate group. In specific sports, as already mentioned, the terms refer to places of activity, athletes, technical and tactical techniques, projectiles, ammunition, quantitative and qualitative concepts [1].

Thus, the terminology of sports activities in a specific natural language can be divided into three conditional categories: the terms of the science of sports, sports terms and industry (used in one or more sports) terms. Recognizing the blurring of boundaries between these layers of sports vocabulary, in our work we will focus, first of all, on the last group. Considering the above, we define a sports term as a linguistic sign (noun, adjective, adverb, verb or phrase) correlated with one of the concepts of a complex and open conceptual system "sport" and having a definition (existing or potential) that allows to identify the concept as sports, and the term as an element of the language of sports.

One cannot but agree that in some cases borrowed words have more specific, precise semantics. However, Uzbek researchers believe that the process of penetration of foreign words is a "clogged language". Uzbek researchers are alarmed by the fact that the emergence of Anglicisms in the Uzbek language is happening all the time, and this gives rise to concerns that the transformation of their language into a certain one will not happen. In connection with this ministry of sports the need for their publication is not in doubt, since English is the official language of the Olympic Committee, and the media, athletes, and spectators speak the language of sports.

A vivid example of the concern of Uzbek linguists about maintaining the "purity" of a language is the description of the meaning of the word fitness in the explanatory dictionary of sports terms: a set of exercises designed to maintain physical fitness with the help of sports equipment. The authors of the dictionary offer the Uzbek equivalent with the same semantics with the use of the word fitness recommendation. An interesting remark is found when explaining the word chalenge (a sports test, overcoming which the athlete receives the title). In the explanatory dictionary there is a special recommendation that it is necessary to refrain from the English pronunciation of its equivalent with the same semantics of the challenge. The same recommendation is also present when interpreting the single-root word chalenger, derived from the English challenger (a person claiming any sporting title). The aim of our work is a lexico-semantic study of some sports terms, which appeared in the Uzbek language by borrowing from the English language, as well as the word-formation analysis of anglicisms in the field of sports.

The material for the study was the Uzbek dictionaries [4]. Often borrowings in the field of sports in the Uzbek language appear from English. This is because many sports have appeared or are popular in the USA and the UK. In tennis, for example, the following English expressions began to be used in Uzbek all the time: top spin (a type of racket strike, in which the ball is hit from the bottom up, giving a strong rotation in the direction of the blow), passing shot (full stroke), full ace (feed to departure), let (uncounted 
feed), break (win the game on the opponent's serve), grip (special tape wrapped around the racket handle). In the field of golf, we refer to Englishman putter (club with a light head), snooker (snooker), pars (the number of strokes during which the golfer must go through the hole according to the rules), birdies (holding the ball into the hole with one less stroke than with "pairs"), bogeys (the number of strikes on the ball is one more than "pairs"), double bogeys (the number of strikes two more than "pairs"). In this kind of sport, like surfing, which is very popular in Europe, the following anglicisms can be noted in Uzbek: roller (rise on the wave during its increase), bottomside (find the shortest path on the wave), cutback (slide on the inside of the wave), deep surf (glide at depth), bodysurfing (the body of the surfer with short flippers on the legs acts as the sliding surface). The list of sports terms that appeared in the Uzbek language through borrowing from English is numerous: bodyboard (surfing while lying on a short soft board), body dynamics (body dynamics), speedway (track motor racing), skateroller (roller-skating), barefoot ski (water skiing), short track ski (short distance skiing). In morphological terms, we meet nouns in the modern Uzbek language with the suffix characteristic of English -ing: tumbling (an acrobatic gymnastics exercise consisting of a series of jumps performed quickly one after another on a narrow long path), trekking (moving on foot region), stretching (gymnastics based on stretching of muscle fibers), rafting (a sport that consists of running down a river with a strong current on a special boat), jogging (running at an average pace at special sites or kind of; warm clothing that is worn over sportswear), coaching (sportsman or team training), bodybuilding (a set of exercises designed to simulate the body), footing (fast paced exercise), pressing (a form of protection that limits action the enemy within the rules), forcing (in the box, the enemy's reinforced attack), bowling (bowling). Comparison of the meaning of the same sports terms in the English and Uzbek languages revealed some cases in which Anglicisms in the Uzbek language have a broader semantics or a completely different meaning. For example, jogging in the Uzbek language, unlike Eng- lish, means not only sports jogging, but also clothing for this type of sports activity. Coaching in a sport like rugby means a bench. The well-known word tennis in the Uzbek language has a double semantics: sport and sports shoes (sneakers). The term dancing from the English "dance process" means in Uzbek language "the place where people dance". Interestingly, the word footing, which translates from English as "pillar", was borrowed from Uzbek with the meaning of "walking". Among the Uzbek sports terms, we can distinguish a common group of verbs and verbal nouns with the suffix typical for English -er: coacher (to train, guide the team, athlete), roller (roller skates), jogger (to run; man who runs; low sports shoes with thick grooved soles, fastened with the help of laces or velcro), surfer (surf). It should be noted that in Uzbek the above-mentioned verbs have the ending -er and belong to the first conjugation group. Analyzing the noun roller, we conclude that it is formed by the substantivization of a verb borrowed from English.

The study revealed another group of sports terms formed by affixing, -er, expressing in the Uzbek language belonging to any profession: jogger (the person who runs), the rafter (the person who rafts), snowboarder (snowboarder), surfer (surfer), player (player), basketball player (basketball player). The next group of Anglicisms in the field of sports is composed of compound words corresponding to the structure of noun + noun: boxer-short (boxing sports shorts), home-trainer (sports exerciser at home), horse-ball (sport, which has two teams, each of which has six riders on horseback, trying to score a special ball to the opponent), tie-break (in tennis, a kind of shortened game with a different account management system compared to other games), a mountain bike (a bicycle designed for uneven surfaces).

The following Uzbek sports terms are combined with a common root token board (board): skateboard, snowboard, snowboard, funboard (short board, equipped with a sail for gliding and jumping on the waves; an acrobatic sport with various tricks on the waves using the board sail). 
Linguists call Uzbek words hybrids, formed by adding two words borrowed from different languages, for example: autocross, autostart (auto from Greek, cross, start from English). Hybrids also include the words tennisman (tennis player), rugbyman (rugby player), which appeared recently in the Uzbek language, the synthetic method of education tennis + man, rugby + man, instead of English expressions tennis player, rugby player. The terms recordman (record holder), crossman (participant in the cross), racingman (race car driver) are formed in the same way. Among the sports terms can be found words that are historically borrowed from Latin from English, and later translated into Uzbek.

In lexical terms, the language is more vulnerable to borrowing than in the field of grammar. This is due to the frequency of repetitions of new foreign words, which leads to their assimilation in the Uzbek language. We share the opinion of A.P. Sedykh, S. S. Sosoyenko that "... thanks to the efforts of " amateurs", professional language is popularized and adapted to the realities of ordinary people's life, begins to actively influence their thinking, enters into the practice of everyday life" [5, C. 187].

The profession of a journalist, a sports commentator often requires the earliest transmission of information to the viewer, the listener, immediate translation from a foreign language, which also leads to borrowing, thanks to the media, when new words and expressions are picked up and begin to be used by fans. According to A. A. Elistratov, sports vocabulary is only partially professional, as physical culture and sports as human activities go beyond the narrow professional interests. [6, C. 122]. Indeed, the media enrich the terminological composition with anglicisms: $\boldsymbol{d r o p}$ (fall), goal (goal), dribble (dribble), penalty (penalty), score (score), corner (corner kick).

\section{Conclusion}

According to L. Derou, there is a significant influence of the English language in relatively new sports, such as football, rugby, golf, tennis, water polo, while in the earlier forms (wrestling, fencing, billiards) there are almost no anglicisms in Uzbek.

As a conclusion, the analysis revealed that the majority of borrowings in Uzbek sports terminology was due to anglicisms. Among them are several groups formed in an affixal way, sports terms with a common root lexeme, as well as complex named constructs. It should be noted that some Anglicisms, going over to the Uzbek language, expand their meaning or acquire new semantics.

\section{References:}

1. Гуреева Е.И. Спортивная терминология в мингвокогнитивном аспекте: автореф. Аис. ... канА. фимол. наук: 10.02.19 / Гуреева Екатерина Ивановна.- Челябинск, 2007.- 24 с.

2. Шафранова Н.А. Семантико-функциональная характеристика спортивной мексики в современном английском языке: Аис. ... канА. филол. наук: 10.02.04 / Шафранова Наталья Александровна.- Пятигорск, 2005.- 239 с.

3. Елистратов А.А. Специфика профессиональной речи спортсменов / А.А. Елистратов // Языки профессиональной коммуникации: Материалы межАунар. науч. конф., 21-22 окт. 2003 г.- Чемябинск: Ин-т языкознания, 2003.- С. 101-105.

4. Ўзбек тилининг изохли муғати. А. МаАвалиев тахрири остиАа (2006-2008) URL:https://ziyouz.uz/ durdona-toplamlar/uzbek-tilining-izohli-lugati/

5. Седых А.П., Сосоенко С.С. К вопросу о современном французском спортивном Аискурсе // Фимологические науки. Вопросы теории и практики. - Тамбов: Грамота, 2013.- № 12 (30).Ч. 1.- С. 184-190.

6. Елистратов А.А. К проблеме стилистической стратификации спортивной мексики // Фикологические науки. Вопросы теории и практики. - Тамбов: Грамота, 2010.- № 1 (5).- Ч. 1.- С. $122-127$. 